\title{
Radical Interdependence: Buddhist Philosophical Foundations for Social Theory
}

\begin{abstract}
This Chapter asserts that a Buddhist perspective provides a systematic and genuine alternative to Western models of IR not so much because it arose in Asia, but because it is founded on distinctive firstorder philosophical principles or substructures that differ from those that dominate in the West. The chapter explains this fundamentally different worldview through the concept of "radical interdependence"-the basic Buddhist "truth" about the nature of our existence that departs from most Western understandings of reality and interdependence. Buddhism offers a different starting point for thinking about the world we live in, one it characterizes as deeply interdependent. Moreover, Buddhism maintains that the failure to appreciate the full extent of interdependence limits our human potential and is the ultimate source of all conflicts, up to and including interstate war, whereas an understanding the truth of radical interdependence is the key to imagining a different vision for politics and IR.
\end{abstract}

Keywords Radical interdependence - Dependent origination - Self . Human nature 


\section{BuddhisM's RADICAL INTERDEPENDENCE}

The concept of radical interdependence is the basis for developing an alternative, global IR theory based on Buddhist philosophy. Before outlining essential Buddhist principles, however, one qualification is in order. Because Buddhism has existed for thousands of years and has spread across Asia and more recently to the West without being organized by a unified institutional authority, it must be noted that there are numerous, divergent forms of Buddhist thought and practice. It is said that Buddha gave 84,000 teachings in all and each of them has been the subject of multiple translations, interpretations, and debates for millennia. With this caveat, it is still possible to distill a fundamental core of commonly held Buddhist tenets (Gethin 1998).

Buddhism asserts that every functioning thing we perceive arises (and ceases) in dependence on its causes and conditions, its parts, and the minds that perceive it; like a rainbow that appears to our senses when heat, light, and moisture come together in a certain manner and dissolves when those conditions change. In its original Pāli transcription, ${ }^{1}$ this principle is known as the doctrine of dependent origination (patica-samuppada in Pāli, in Sanskrit, pratitya-samutpada) expressed poetically in the verse:

When this is, that is

This arising, that arises

When this is not, that is not

This ceasing, that ceases (SN.12:61).

The doctrine asserts that reality (including our "self") lacks a fixed, inherent, or essential nature (a concept known as anātta in Pāli, anātman in Sanskrit) and, on analysis, can be decomposed into other, simpler elements, ${ }^{2}$ and that all things are impermanent (anicca in Pāli, anitya in Sanskrit), the product of ever-changing causes and conditions.

The individual self, for example, at any given moment is in fact made up of various physical and mental elements (aggregates), ${ }^{3}$ and the notion of an enduring self is illusory, albeit an illusion that is hard to dispel. ${ }^{4}$ This approach is known as a "reductionist" definition of the self, which differs from so-called "essentialist" approaches to the self that dominate in the West. ${ }^{5}$ For certain functional purposes, one may choose to refer to selves or objects in keeping with worldly conventions, but ultimately the self and other phenomena lack a fixed, inherent nature in Buddhist thought. The conventional reference to the self and other objects, up to and including 
nation-states, is meaningful if properly understood, however, because it can serve practical, functional purposes and because it can eventually lead one to understanding the ultimate nature of things through sustained analysis. $^{6}$

Given this reductionist understanding of "self" and all objects of existence, radical interdependence maintains that the alleged separation between self and others and between enduringly real subjects and objects, which is the Archimedean starting point (ontologically) for realist, liberal, and even many constructivist approaches ${ }^{7}$ to politics in the West, is ultimately incorrect, a misperception. According to Buddhism, the alleged separation is a "delusion" or "ignorance" (of the nature of reality). Instead, a Buddhist social paradigm necessarily begins with the fundamental truth of the essential interdependence and impermanence of all reality, including ourselves (the no-self doctrine). It asserts a radical interdependence between individuals and between humans and their social and natural environments. This Buddhist ontology is analogous in modern thinking to a form of radical relationalism in Western social thought and quantum theory in the natural world, a point I return to in the concluding chapter.

Epistemologically, this means the notion of fixed, objective reality is an impossibility. Given that the only ultimate truth is the lack of inherent existence, all other forms of knowledge are provisional or "conventional" truths. It is important to reiterate, however, that our conventional notions of reality are a form of truth in that they can help us function in the world and, when used correctly, can lead individuals to a realization of ultimate truth, which is the source of liberation from suffering in Buddhism. Because conventional truths perform practical and soteriological functions, Buddhist epistemology has developed a sophisticated literature regarding what constitutes "reliable forms of knowledge," (pramānas, in Sanskrit), generally held to be a product of our direct perceptions or logically drawn inferences. In seeking reliable knowledge, Buddhism emphasizes personal experience, a pragmatic attitude, and the use of critical, skillful, and contextual thinking toward all types of knowledge, including Buddhist teachings! Buddha did not ask for blind faith or allegiance: "One must not," Buddha says, "accept my Dhamma from reverence but first try it as gold is tried by fire" (Jayatilleke 2008).

Misunderstanding the deeper, radically interdependent nature of reality has severe consequences, according to Buddhism. It leads to problematic actions (karma) ${ }^{8}$ that result in suffering (dukkba in Pāli, dubkha, in 
Sanskrit). Grasping and cherishing a false sense of independence and a desire for permanence keeps us locked in pervasive suffering (samsara in Pāli or Sanskrit). In short, all our problems, including complex political problems, and all the unwanted consequences of our actions flow from a basic misunderstanding of the radical interdependence of reality. As the twelfth century Buddhist monk, Geshe Chekowa instructs in his Seven Points in Training the Mind, "Place all blame on the one." By this he means blame the delusion of self-grasping and self-cherishing as the true source of all our problems and suffering. Buddha's teachings, beginning with his first teaching on the Four Noble Truths, are designed to illuminate ( 1 ) the problem of suffering (birth, aging, sickness, death, and existential uncertainty); (2) its source (self-grasping ignorance); (3) its means of cessation (awakening to an understanding of the true nature of reality and ourselves); and (4) the path to the cessation of suffering (mindful ethical behavior and meditation to inculcate virtue and wisdom $){ }^{9}$

This fundamental mistake leads to reifying oneself and objects of desire or aversion in the belief that protecting and cherishing ourselves and our desires and harming and destroying our enemies and aversions will bring us security and happiness. This tendency is only made worse in collectives, like states, nations, and institutions, which are projections based on a false premise (Macy 1979). Paradoxically, and directly contrary to our ordinary belief, self-reification and grasping at self and objects, from a Buddhist perspective, do not bring happiness but only discord and dissatisfaction. The championing of the autonomous and independent self (and, necessarily, an alien other), from a Buddhist viewpoint, will not promote individual or social well-being. Instead this dualistic thinking will produce dissatisfaction, personal insecurity, incessant striving, conflict, and violence. Taken to its logical conclusion, clinging to an autonomous self and exalting self-interest are the sources of social and political division, and they perpetuate political systems, including our current international system, which have created military and environmental threats that could consume us.

The Buddhist ontology of interdependence and impermanence leads to a different starting point for the social/political world and individual wellbeing and a way out of this dilemma. Buddhism is the basis for a politics of radical interdependence and, ultimately, what Buddhists call "fearlessness," that is, caring equally for others' welfare. The latter connotes that individuals bave the potential of overcoming perceived duality and 
accepting the creative possibilities and moral responsibility of open-ended impermanence and interdependence. According to Buddha, one's nature, when realized through training the mind to understand the true nature of reality, makes equanimity, unselfishness, and cooperation our natural, underlying social disposition, not self-interest, because caring equally for all is only logical when one fully realizes the truth of our radical interdependence. Human nature in Buddhism contains the essence of enlightenment, a fully awakened being, called our "Buddha nature" in some Buddhist schools. ${ }^{10}$ This alternative view of human nature is the second major difference between Buddhist social theory and those of the West, a difference that follows from the first and fundamental difference: the Buddhist assertion that all reality is radically interdependent. As will be discussed in the next chapter, our political systems can and should, therefore, reflect and support individuals in recognizing this fundamental truth and in realizing their underlying nature.

Buddhist ontology encourages our connection with, not separateness from, others. By this logic, empathy (feeling with others) is fundamental to human nature, and altruism (acting on behalf of others) and cooperation are humans' deep-seated behavioral traits, our fundamental and unbound nature. Separateness and selfishness are the result of pervasive but mistaken conceptions that lead to negative actions-greed (attraction to objects that do not exist as they appear and do not endure), anger (aversion to such false objects), false pride, and jealousy-and thus suffering. Buddhist logic does not deny the prevalence of our more selfish or conflictual traits. Instead, Buddhism suggests only that a selfish, fearful orientation is not humans' fundamental nature and therefore ultimately is an erroneous starting point for designing political institutions and policies. While Buddhism acknowledges that individuals may behave in selfish or discordant ways, this behavior is considered the result of "adventitious defilements," like mud in water. Because these defilements are not part of one's true nature, they can be removed by following the teachings to reveal a root mind which is clear, altruistic, compassionate, and wise, like a Buddha's. For Buddhists, an innate empathetic and altruistic orientation is a real possibility because it accords with the how things actually exist, i.e. interdependently, and it is an option that can be chosen and worked toward.

Buddhism does not disagree with Western philosophers that selfinterest appears to drive most behavior. But it does differ when we ask the question: "What is the base-line position regarding the social emotions 
and thoughts that form our human nature?" Is our root nature fundamentally self-interested or altruistic? Clearly, ample evidence can be found in everyday social behavior to suggest that self-interested behavior is ubiquitous. But pointing to evidence of selfish behavior may mislead us about human's root nature. Just as we "see" physical reality as corresponding to classical propositions of subject-object dualism (although, for Buddhists, reality ultimately does not exist this way), Buddhism would argue that, despite their appearances, we are mistaken about the ultimate reality of our human nature, too, and our prescriptions for social behavior reflect that basic misunderstanding.

Buddhism asserts that human beings only behave in ways that are selfish and often discordant if they misperceive the real nature of their existence and if they suffer from delusions about the nature of themselves and reality. If individuals remain attached to the notion of themselves as separate from, and in opposition to, other selves and all other things (the classical Western ontology), when push comes to shove they will act predominantly in selfish and non-cooperative ways. From a Buddhist perspective, individual and social pathologies such as violence and destructiveness, or merely sub-optimal levels of cooperation, are ultimately linked to misguided efforts to find certainty and separateness in a world that is indeterminate and interdependent, not from our basic makeup.

According to Buddhism, the mistaken feeling of duality between the world and "us" feeds our incessant insecurity and fears and drives our preoccupation with power and control over others and our environments to secure ourselves. Averring the truth of this duality, Western political thinkers typically begin their social thinking with the dilemma of how, through the social contract, to control the clash of interests seen as inherent in human individualistic pursuits and thereby secure the benefits of social order without unduly constricting individual freedom. This alleged dilemma has been the starting point for all Western contract theories of social organization from Hobbes to Rawles. Buddhism does not begin with the self at the center of the universe but describes a decentered world, where what is to be feared are delusions of independence that keep humans in suffering, rather than fearing perceived external threats to the security of what they consider a constructed self.

This depiction of human nature and natural conduct is not intended to suggest that there is an inevitable nexus between an intellectual understanding of our ontological status and social behavior in practice. Unfortunately, it is not that simple. Rather, Buddhist ontology 
provides a paradigmatic orientation that can unlock thinking about certain social possibilities that are fundamentally different from those based on Western, Cartesian assumptions. Buddhist philosophy does not change the widespread expression of selfish behavior; rather it treats that behavior not as human beings' ultimate nature, but as our choice, albeit a choice made under the pervasive delusion of duality. For Buddhists, dualistic thinking based on independent selves and objects is a constructed reality that can be deconstructed, not so much through clever philosophical discourse, but through hard work via mindfulness and meditation that teaches one to recognize and transform one's own thoughts, intentions, and emotions and the behaviors that ultimately flow from them.

Because, in Buddhism, political and economic systems necessarily reflect the mentality of the individuals within them, that is to say, our present world is the expression of the collective karma (actions) of its inhabitants, the starting point of the work needed to recognize a more cooperative society is self-transformation, but government, the economy, and even the international system can structure themselves consistent with the fundamental wisdom of radical interdependence to provide supportive environments for the attainment of humans' true nature and lasting happiness. ${ }^{11}$ These helpful social provisions are known as "conducive conditions" in Buddhism. Buddhist social and political designs are instrumental: they exist not for their own sake, but as an important means for supporting individuals' progress along a path that culminates in wisdom and transcendence of suffering. In Buddhist metaphorical language, these conditions are a raft that carries us to the other shore, not an end in themselves.

Radical interdependence as the nature of existence applies equally across the different "levels of analysis" in IR (individual, state, and state system), with primacy/originality given to the individual level. States and the state system are the summation, projection, and institutionalization of individual ways of thinking, an intersubjective consensus, as constructivists would say. The underlying nature of the state and state system is contingent on the individuals who compromise them, an assertion that reflects Buddhism basic humanism. ${ }^{12}$ As discussed, these individual selves, in turn, lack a permanent essence. Individuals, states, and the state system are, therefore, all changeable phenomena. Individuals have the capacity to shape the character of their minds, and thereby, their institutions, such as the state and the state system (Chavez-Segura 2012). The scientific basis of these assertions is touched on in the final chapter. 
Peace and social progress, therefore, depend ultimately on the individual. At an individual level, the ontology of radical interdependence and no-self implies an alternative ethics or way of being in the world. Primarily, this view encourages a reduced attachment to self and thus undercuts selfishness-the basic Western assumption about human nature (Harvey 2000). The movement away from an essentialist self toward noself implies "a drift toward impartiality and impersonality, a lessening of the gap between persons since my relation to others is not so significantly different from my relation to my own past and future" (Perrett 2002 at p. 375). By focusing more on a collection of experiences and less on an immutable self, we can view others and ourselves with greater equanimity. Through familiarity with no-self, a person experiences reduced egoistic concern and recognizes that the pursuit of her own welfare is not fundamentally different from her regard for the well-being of others. Operating under this ontological stance means our responsibility to our future selves rests not on selfishness, but largely on a pragmatic rationale: we are well situated to affect the well-being of ourselves (and our intimates), and therefore should act to promote the welfare (or reduce the suffering) of those we are in the best position to help. Moreover, failure to look after our "self" would make us of little value to "others." This immediate concern, however, does not detract from our obligation to avoid harming and to promote the welfare of others more distant from ourselves to the extent we can do so. The Buddhist path for achieving this level of personal development is reducible to ethical conduct and shaping our thoughts and emotions to remove negativity and replace it with positive thoughts and emotions (such as generosity and compassion) through the practice of mindfulness, concentration, and meditation. These same practices can also lead ultimately to an "awakening" to the wisdom that realizes radical interdependence directly. This worldview is directly opposed to the egoism, separation of self from other, fear, insecurity, competition, domination, conflict, violence, and revenge that have traditionally been considered natural elements of politics and IR in the West. ${ }^{13}$ Radical interdependence, if realized, can lead instead to a sense of connection, community, tolerance, responsibility, and ultimately, a universal sense of humanity and a greater willingness to find common purpose according to Buddhism. As individuals develop these abilities, by extension, they 
develop more peaceful and cooperative social institutions, which, in turn, support individuals in their material and spiritual ambitions. The next chapter looks at the nature of the social and political institutions that Buddhism prescribes.

\section{Notes}

1. Buddha's words were first transcribed in the Pâli Canon. I rely on it to distill Buddha's ideas about the political world in Chapter 3. The Pāli Canon is the earliest authoritative text of Buddha's teachings. It is often called the Tipitaka ("three baskets") and includes the vinaya, disciplines for the monastic order; sutras, discourses; and the abhidharma, further teachings of a philosophical and psychological nature.

2. One could go further with this ontological inquiry and ask "What, then, is the ontological status of the parts or aggregates that make up the objects we perceive?" This is a very complex question and has spawned numerous different schools of thought about fundamental ontology in Buddhism, much like in the West. Some early Buddhists were philosophically "realist," arguing that the elements of existence, while reducible to simpler parts or causes, were ultimately materially real and truly existent (the Vaibhāṣika school, for example). Other Buddhist traditions, such as certain branches of the Sauträntika school, maintained that elemental particles of reality are representationally real, i.e., that both cognition and external objects have some ontological status, analogous to Western critical realism. Still other Buddhist schools, like the Cittamātra, or the Yogācāra, are comparable to Western philosophical idealists, asserting that all phenomena are the same nature as the mind that apprehends them and do not exist external to the mind. Buddha, himself, eschewed discussions of metaphysics for a pragmatic approach to human problems. The spirit of Buddha's anti-metaphysical stance is adopted in the Middle Way (Madhyamaka) philosophy captured most systematically in the works of Nāgārjuna (second century CE). This approach also has sub-schools within it, but in Nāgārjuna's Madhyamaka-Prasangika philosophy, he adopts a skeptical or what we might call deconstructivist or post-modern orientation to ontological assertions. Nāgārjuna, and his followers clarified the argument that all phenomena are empty ('sunnya) of inherent existence, but can be usefully understood to exist conventionally and provisionally. He argued for a "Middle Way," which, in this context, means steering a path between eternalism (things have a fixed and enduring nature) and nihilism (everything is relative and our reality has no meaning). In the Madhyamaka, conventional, ever-changing truth is still meaningful because it allows the law of karma (cause and effect) to operate-if reality were fixed and 
inherently real, such changes would not be possible, and one could not make progress along the spiritual path to enlightenment. According to this school, eventually one can come to understand that all phenomena have both a conventional and ultimate nature (emptiness) and the two natures are non-contradictory or unified. For example, emptiness is not an abstraction apart from conventional reality; emptiness is always the ultimate nature of some conventional object. Colloquially, ultimate and conventional truths are two sides of the same coin. Nāgārjuna did not offer these insights as affirmative ontological claims, but only as methods for deconstructing all other ontological assertions that might stand in the way making the changes necessary to liberate ourselves from suffering.

3. These "aggregates" (skandhas, in Sanskrit, khandhas, in Pāli) that make up persons include: (1) material composition or form; (2) sensations (feelings); (3) perception; (4) mental activity (formations); and (5) consciousness. Clinging to these aggregates as inherent real rather than recognizing their evanescent nature is a fundamental mistake that leads to suffering.

4. Buddhists, unlike Western thinkers such as David Hume discussed in the footnote below, believe that it is possible to realize the non-essential nature of the self (the no-self) and necessary to try to do so to liberate oneself from suffering.

5. Reductionism argues that one's existence or continuity as a person can be understood as reducible to certain other facts about physical or psychological connectedness that are ontologically more basic than the individual. The mind links together closely related mental and physical states to fabricate the notion of a self that continues across time (Parfit 1984). Dismantling this artifice of self requires sustained analysis, contemplation, and meditation. Essentialism asserts that the self or individual typically is considered to have an essence: persons are separately existing entities, distinct from their brains and bodies and their experiences or, alternatively, persons are wholly and solely their brain and body. In the former case, the argument is that, in addition to the various parts that contribute to the psychophysical complex of the person, one extra part constitutes the core or essence of the system. An essentialist approach tends to refer to this special part as the "self." There are many candidates for what constitutes this non-reducible essence. For Plato, this essence was the immaterial and immortal soul. For Augustine, an immaterial soul and material body makes one self, and, for others, some brute physical continuity (usually the brain) constitutes the self. The latter notion, that is, the self as the total person (mind and body), accords with our commonsensical notion that we simply "are who we are," a physical and mental system that persists as a single entity from one period to the next, ending perhaps at death. Either 
way, ontologically, this self persists over time and has genuine autonomous causal and explanatory powers that cannot be reduced to the causal and explanatory powers of its constituent parts. Although essentialism is the historical norm for understanding the nature of the self in the West, the range of thinking is wide, and a minority of Western philosophers gravitate toward the reductionist end of the spectrum. Kant, Nietzsche, and Heidegger all have reductionist views of the self, for example. At the far end of the spectrum, a very few Western philosophers, such as David Hume, reject the notion of self or personal identity. It is possible that Hume was familiar with Buddhism (Gopnik 2009). Hume does not posit a substantial self that exists beyond one's experiences. (Giles 1993). How then do we account for the everyday perception of a self? Hume explains that we misconstrue this flow of diverse perceptions as an enduring identity because the many independent experiences resemble each other. When successive perceptions resemble each other, it is easy for us to imagine that the first simply persists. Our imaginative propensity to misconstrue an identity from diversity begins in infancy and continues unabated without our awareness of the misperception. For Hume, discussions about the self are merely verbal exercises. The self then can be addressed at two levels: on ultimate or metaphysical terms where we should recognize that there is no self; and on a conventional, verbal, or grammatical level of social standard, where it can be convenient or useful to designate a self (Hume 1739 [2000]). Buddhists reached the same general conclusion 2000 years previously.

6. These so-called "conventional truths" are only true in the sense that they function to achieve our conventional purposes-like a tea kettle functions to help make a cup of tea, but it does not exist in an ultimate sense apart from its parts (handle, spout, etc.) or our designation of its parts as a "kettle." Conventional "truth" is truth in that it can be distinguished from conventional falsehoods. The kettle on the stove is a conventional truth, whereas averring the reflection of a kettle in a mirror as a kettle is a conventional falsehood in that it will not function in an everyday sense to help us make tea. Conventional reality is known as the second truth of reality in the doctrine of the Buddhist doctrine of the "two truths." The two truths doctrine maintains that the self and objects of existence have both a conventional and an ultimate nature.

7. "Constructivism" is a label that has been applied to a wide range of theoretical approaches. As to constructivism's underlying ontological assumptions, that is, its assertions about how the things theorized about ultimately exist, these run the gamut from Alexander Wendt's so-called "rump materialism" which he equates with the scientific realist notion that our ideas ultimately refer to something that is mind independent to 
more post-modern, interpretive constructivism that argues it is impossible to divorce the seer from the seen and that all reality is mind-dependent, what is known as philosophical idealism. It should be noted that such distinctions are complicated by the fact that Wendt's understanding of scientific realism differs from how others generally use this term, and, by the fact that Wendt also refers to himself as an idealist in the same work in which he claims to be a scientific realist! (see Rivas 2010). Perhaps not surprisingly, some constructivists (and most realist and liberal scholars) avoid directly addressing the fundamental ontological foundation for their theories.

8. The law of karma is a special instance of the law cause and effect which maintains that all our actions of body, speech, and mind are causes and all our experiences are their effects. Karma means "action" or "volition" and refers specifically to the mental intentions that initiate any action. Ignorance (of the nature of reality) is considered the root mental karmic cause of human suffering.

9. Buddha did not teach to establish a religion or philosophical school but to offer others a means to reduce and ultimately eliminate their suffering. After his enlightenment, Buddha's first teaching was that of the Four Noble Truths, and the first of these is that "one must know suffering." Human suffering includes manifest forms such as the pains of birth, aging, sickness, and death. But in addition to encountering those things that cause us pain, because of our very impermanence, we will also suffer from being parted from the things we love and the failure to ever fully satisfy our desires for permanent worldly happiness. Temporary pleasures, then, are merely transitory relief from our manifest suffering. It is not that things like family, career, and pleasurable pursuits are not enjoyable; rather it is the mistaken belief that they can endure that leads to suffering. Inescapably, realization of our existential dilemma makes all our pleasures temporary, fleeting, and ultimately in the nature of suffering. Moreover, given the Buddhist teaching of rebirth, one cycles through these sufferings again and again in one life after another without control or freedom, what is known in Sanskrit as samsara, or "pervasive suffering." The Second Noble Truth reveals the origin of our suffering: namely, our craving and grasping at self and objects that are impermanent and unable to provide true happiness. This self-grasping ignorance leads us to perform innumerable negative actions motivated by anger and attachment. Further, given the "law of karma" that maintains that all actions have their similar corresponding effect, our negative actions will necessarily perpetuate suffering for us now and in the future. Thankfully, in the Third Noble Truth, Buddha explains that we can change our negative karma by good thoughts, words, and deeds leading eventually to a cessation of our 
suffering by abandoning grasping at self and phenomena and awakening to our true compassionate nature having removed our delusions and come to understand how things truly exist. In Buddhism, the underlying nature of our mind is clear, luminous, and discerning (in that it understands the true nature of reality). With discernment comes liberation for ourselves and spontaneous compassion for all similarly suffering beings. Ignorance is a curable disease. We must come to recognize that our reality is impermanent, there is no self and all things are interdependent; failing to recognize these truths is the source of our dissatisfaction. Lastly, in the Fourth Noble Truth, Buddha sets out the way to end suffering and achieve a state beyond sorrow, nirvana, and invites everyone to examine and experience the effects for themselves. The Eightfold Noble Path is a means to that end and has three dimensions to it: wisdom ( $\operatorname{raj} \tilde{n} \bar{a})$, mental discipline $(s a m \bar{a} d h i)$, and morality (sìla). The Eightfold Path includes eight stages of ethical management: (1) right view, (2) right intention, (3) right speech, (4) right action, (5) right livelihood, (6) right effort, (7) right mindfulness, and (8) right concentration. The elements of the path are offered as mutually supportive, and at the heart of the matter is wisdom, which is the realization of the true nature of reality. The path, then, might be distilled down to practicing moral behavior and concentrating/meditating on and inculcating virtues to train the mind and lead it to the realization of wisdom.

10. The concept "Buddha nature" is complex and the subject of intersectarian doctrinal disputes. One debate surrounds the question of whether "Buddha nature" is best interpreted as a potentiality yet to be fulfilled or as an actuality as yet unrecognized. Another debate surrounds the question of how to reconcile the notion of an essential Buddha nature with the notion of impermanence and emptiness. Both debates draw from a variety of root texts and have generated extensive commentaries that, while fascinating, will not be engaged here.

11. Happiness has a meaning in Buddhism that is distinct from the West. This topic is addressed in Chapter 5.

12. Alexander Wendt calls this integrative approach from the individual level of analysis through the analysis of the international system of states a "holistic" approach to IR theory (Wendt 1999).

13. In Western political theory, a realist ontology is the underpinning for a politics of separateness and fear, captured most artfully in the work of Thomas Hobbes. By extension, in the international realm, this notion of separation, insecurity, and violence is supported most strongly by Political Realists. 


\section{REFERENCES}

Chavez-Segura, Alejandro. 2012. A Tibetan Buddhist Approach to International Relations: The Teachings of the Dalai Lama. Lewiston: Edwin Millen Press.

Gethin, Rupert. 1998. The Foundations of Buddhism. New York: Oxford University Press.

Giles, James. 1993. The No-Self Theory: Hume, Buddhism, and Personal Identity. Philosophy East and West 43 (2): 175-200.

Gopnick, Alison. 2009. Could David Hume Known About Buddhism? Charles Francis Dolu, the Royal College of La Fleche, and the Jesuit Intellectual Network. Hume Studies 35 (1\&2): 5-28.

Harvey, Peter. 2000. An Introduction to Buddhist Ethics. Cambridge: Cambridge University Press.

Hume, David. 1739 [2000]. An Enquiry Concerning Human Understanding. New York, NY: Oxford University Press.

Jayatilleke, Kulatiss. 2008. Buddhism and Peace. Buddhist Publication Society. Available online at http://bps.lk/olib/wh/wh041_Jayatillake_Buddhismand-Peace.pdf.

Macy, Joanna Rogers. 1979. Dependent Co-Arising: The Distinctiveness of Buddhist Ethics. Journal of Religious Ethics 7 (1): 38-52.

Parfit, Derek. 1984. Reasons and Persons. New York, NY: Oxford University Press.

Perrett, Roy. 2002. Personal Identity, Minimalism, and Madhyamaka. Philosophy East and West 52: 373-385.

Rivas, Jorge. 2010. Realism for Real this Time: Scientific Realism is not a Compromise between Positivism and Interpretivism. In Scientific Realism and International Relations, ed. Colin Wight, 203-227. London: Palgrave Macmillan.

Samyutta Nikáya (SN). 2000. The Connected Discourses of the Buddha, trans. Bhikkhu Bodhi. Boston, MA: Wisdom Press.

Wendt, Alexander. 1999. Social Theory of International Politics. Cambridge: Cambridge University Press. 
Open Access This chapter is licensed under the terms of the Creative Commons Attribution 4.0 International License (http://creativecommons.org/licenses/ by $/ 4.0 /$ ), which permits use, sharing, adaptation, distribution and reproduction in any medium or format, as long as you give appropriate credit to the original author(s) and the source, provide a link to the Creative Commons license and indicate if changes were made.

The images or other third party material in this chapter are included in the chapter's Creative Commons license, unless indicated otherwise in a credit line to the material. If material is not included in the chapter's Creative Commons license and your intended use is not permitted by statutory regulation or exceeds the permitted use, you will need to obtain permission directly from the copyright holder.

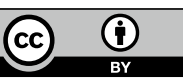

